\title{
Analisis Interaksi Model Pembelajaran dan Berpikir Kritis Terhadap Hasil Belajar Siswa Pada Materi Pokok Suhu dan Perpindahan Kalor Kelas X Semester II SMA Negeri 16 Medan
}

\author{
Ratelit Tarigan \\ Prodi Pendidikan Fisika FMIPA Universitas Negeri Medan \\ ratelit.tarigan88@gmail.com
}

\begin{abstract}
The research aim is known influence of interaction between learning model and ability level of critical thinking from learning outcomes of physics. Type of this research is quasy experiment with two group pretest-posttest design. The population of this research are all the students $X$ grades semester II, which consist of four classes with cluster random sampling which X-Mia 3 as experiment class and X-Mia2 as controlling class. The instrument to take data of outcomes learning is essay test with 8 questions and test of critical thinking in essay in 10 questions. Both of questions are validated of 4 validations to resulting valid instrument. The instrument of learning outcomes which have valid applying for students before studying activity. In the start of study, the student is given critical thinking question and then analyzing the data, interaction between learning model and level of high ability critical thinking for outcomes learning of physics. In conclusion, model of learning more domain than level of outcomes learning ability to critical thinking.
\end{abstract}

Keywords: Problem Based Learning, Learning outcomes, Critical Thinking

\begin{abstract}
Abstrak: Penelitian ini bertujuan untuk mengetahui pengaruh intreaksi antara model pembelajaran dan tingkat kemampuan berpikir kritis tinggi terhadap hasil belajar fisika. Jenis penelitian ini adalah quasi eksperimen dengan two group pretest-posttest design. Populasi dalam penelitian ini adalah seluruh siswa kelas X semester II yang terdiri dari 4 kelas. Pengambilan sampel dilakukan dengan cara cluster random sampling yaitu kelas $\mathrm{X}-\mathrm{Mia}_{3}$ sebagai kelas eksperimen dan kelas $\mathrm{X}-\mathrm{Mia}_{2}$ sebagai kelas kontrol. Instrumen yang digunakan untuk pengambilan data hasil belajar dalam bentuk essay dengan jumlah 8 soal dan tes berpikir kritis dalam bentuk essay dengan jumlah 10 soal. Kedua soal divalidasi oleh 4 validator sehingga menghasilkan instrumen yang lebih valid. Instrumen tes hasil belajar yang sudah valid diterapkan terhadap siswa sebelum dilakukan kegitan belajar mengajar (ujiawal). Awal pembelajaran diberikan soal berpikir kritis, kemudian data tersebut dianalisis, menghasilkan terdapat interaksi antara model pembelajaran dan tingkat kemampuan berpikir kritis tinggi terhadap hasil belajar fisika. Dalam hal ini, model pembelajaran lebih dominan dibandingkan dengan tingkat kemampuan berpikir kritis terhadap hasil belajar siswa
\end{abstract}

Kata Kunci: Pembelajaran Berdasarkan Masalah, Hasil Belajar, Berfikir Kritis

\section{PENDAHULUAN}

Semua pasti sudah menyadari bahwa pendidikan itu penting, bahkan sangat penting. Oleh karena itu, para pakar pendidikan berupaya menciptakan cara belajar dan mengajar yang efektif dan efisien untuk diterapkan. Tentu saja tujuannya untuk memajukan pendidikan yang juga berarti memajukan nasib bangsa. Telah banyak inovasi yang diterapkan, mulai dari belajar di ruang kelas yang nyaman sampai belajar di alam terbuka. Tapi, seiring dengan perkembangan ilmu pengetahuan dan teknologi, cara belajar dan mengajar pun semakin canggih dan modern. Perkembangan ilmu pengetahuan dan teknologi, tidak terimbas ke guruguru, khususnya guru di daerah. 
Penguasaan fisika di Sekolah Menengah Atas (SMA) menjadi salah satu modal dasar dalam pengembangan berbagai bidang keahlian. Fisika sebagai ilmu bidang sains merupakan salah satu mata pelajaran yang berhubungan dengan alam sehingga dalam pembelajarannya diperlukan penyelidikan berupa percobaan terhadap pengetahuan tersebut. Proses pengembangan suatu bidang ilmu fisika diperlukan sarana dan prasarana yang mendukung seperti laboratorium dengan peralatan dan alat-bahan percobaan fisika yang memadai, perpustakaan yang cukup untuk mengembangkan dasar berpikir siswa, dan penunjang pembelajaran lainnya di sekolah.

Berdasarkan hasil studi pendahuluan pada tanggal 8 Januari 2015 yang dilakukan oleh peneliti pada salah satu kelas X SMA Negeri 16 Medan, peneliti menemukan rendahnya keterampilan berpikir dan memecahkan masalah pada pelajaran fisika. Hal ini didapat dari hasil angket yang disebarkan kepada siswa, untuk mengetahui bagaimana tanggapan siswa terhadap pelajaran fisika. Berdasarkan instrumen angket yang disebarkan kepada 42 siswa kelas X di SMA Negeri 16 Medan, diperoleh bahwa siswa masih sulit dalam menyelesaikan masalah dan masih sulit untuk menentukan kapan harus menggunakan prosedur yang sesuai terhadap sesuatu yang baru atau masalah-masalah baru dalam fisika.

Kesimpulan tersebut diperkuat oleh pernyataan melalui hasil wawancara dengan salah satu guru fisika SMA Negeri 16 Medan, mengatakan bahwa pembelajaran fisika diajarkan dengan model konvensional yang terdiri dari metode ceramah dan presentase. Dalam metode presentase dimana guru menyajikan materi melalui laptop kemudian dijelaskan kepada siswa. Guru cenderung memindahkan pengetahuan yang dimiliki kepikiran siswa, mengajarkan secara urut halaman per halaman tanpa membahas keterkaitan antara konsep-konsep atau masalah, mementingkan hasil dari pada proses. Siswa menjadi pasif dan kurang terlibat dalam proses belajar mengajar. Sekolah memiliki laboratorium namun pembelajaran cenderung dilakukan di dalam kelas, sehingga sebagian besar siswa kurang mampu menghubungkan antara apa yang dipelajari dengan bagaimana mengaplikasikannya pada situasi nyata.

Menanggapi permasalahan di atas perlu adanya model pembelajaran yang bisa menciptakan keterlibatan siswa dalam proses belajar mengajar untuk mengembangkan keterampilan berpikir dan menumbuhkan kemampuan memecahkan masalah siswa. Membiasakan bekerja ilmiah diharapkan dapat menumbuhkan kebiasaan berpikir dan bertindak yang merefleksikan,penguasaan,pengetahua,keterampilan dan sikap ilmiah yang dimiliki siswa, sehingga dengan sendirinya model pembelajaran itu akan berakibat pada meningkatnya pengetahuan, keterampilan dan sikap ilmiah siswa sebagai hasil belajar.

Menurut Arends (2008) model pembelajaran berdasarkan masalah (Problem Based Learning) merupakan model pembelajaran yang mengorgansisasikan pembelajaran di sekitar pertanyaan dan masalah, melalui pengajuan situasi kehidupan nyata yang otentik dan bermakna, yang mendorong siswa untuk melakukan proses penyelidikan dan inkuri, dengan menghindari jawaban sederhana, serta memungkinkan adanya berbagai macam solusi dari situasi tersebut. Dalam pembelajaran berdasarkan masalah keaktifan siswa lebih diutamakan karena kegiatan dalam pembelajaran berdasarkan masalah meliputi pengamatan terhadap masalah, merumuskan terhadap hipotesa, perencanakan penelitian sampai pelaksanannya, hingga mendapatkan sebuah kesimpulan yang merupakan jawaban atau pemecahan permasalahan yang diberikan.

Model pembelajaran berdasarkan masalah adalah salah satu upaya solusinya, model pembelajaran ini merupakan suatu model pemberlajaran yang didasarkan pada banyaknya permasalahan yang membutuhkan penyelidikan autentik yakni penyelidikan yang membutuhkan penyelesaian nyata dari permasalahan yang nyata. Model pembelajaran ini membantu siswa mengembangkan kemampuan berfikir dan mengembangkan kemampuan 
dalam memecahkan masalah kehidupan sehari-hari, sehingga siswa lebih paham terhadap konsep fisika yang berkaitan dengan kehidupan sehari-hari. Menurut Trianto (2011) pembelajaran berdasarkan masalah merupakan pendekatan yang efektif untuk pengajaran proses berpikir tingkat tinggi.

Beberapa penelitian telah menunjukkan dampak positif dari implementai model pembelajaran berbasis masalah. Dalam jurnal Implementation of Problem-Based Learning (PBL) in Foundation Physics Subject oleh Ahmad Hadi Alimenyimpulkan Pembelajaran berbasis masalah dapat menjadi pondasi keberhasilan belajar fisika dilihat dari beberapa keahlian atau keterampilan generik berkembang di antara mahasiswa seperti kepemimpinan, interpersonal dan Kemandirian keterampilan belajar. Begitu juga dalam Jurnal Penelitian olehYunita Kustyorini dan Mohan Taufiq Mashuri pengajaran pembelajaran berbasis masalah menunjukkan bahwa adanya pengaruh terhadap aktivitas dan hasil belajar siswa. Hal ini dapat dilihat dari nilai rata-rata postest di kelas eksperimen 78,30 sedangkan di kelas kontrol 71,64.

Salah satu keunggulan dari model pembelajaran berdasarkan masalah adalah kemampuannya dalam mengembangkan kemampuan berpikir kritis. Berpikir kritis adalah proses untuk membuat keputusan yang masuk akal tentang apa yang harus dipercaya dan apa yang harus dilakukan (Robert H Ennis: 1996). Menurut Paul, Fisher dan Nosich (dalam Fisher, 2009 : 4) berpikir kritis adalah mode berpikir mengenai hal, substansi atau masalah apa saja, dimana si pemikir meningkatkan kualitas pemikirannya dengan menangani secara terampil struktur-struktur yang melekat dalam pemikiran dan menetapkan standar-standar intelektual padanya.

Pada dasarnya keterampilan berpikir kritis dikembangakan menjadi indikator-indikator keterampilan berpikir kritis yang terdiri dari lima kelompok besar yaitu (1) Memberikan penjelasan sederhana, (2) Membangun keterampilan dasar, (3) Menyimpulkan, (4) Memberikan penjelasan lebih lanjut, (5) Mengatur strategi dan taktik, Blom (dalam Filsaime, 2008).

Adapun tujuan penelitian ini yaitu 1) Untuk mengetahui hasil belajar siswa kelas X SMA Negeri 16 Medan pada materi pokok Suhu, Kalor dan Perpindahan Kalor sesudah pembelajaran dengan menggunakan model pembelajaran berdasarkan masalah, 2) Untuk mengetahui hasil belajar siswa kelas X SMA Negeri 16 Medan pada materi pokok Suhu, Kalor dan Perpindahan Kalor sesudah pembelajaran dengan menggunakan model konvensional, 3) Untuk mengetahui pengaruh model pembelajaran berdasarkan masalah terhadap hasil belajar siswa pada materi pokok Suhu, Kalor dan Perpindahan Kalor di kelas X IPA SMA Negeri 16 Medan semester genap T.P 2014/2015, 4) Untuk mengetahui hubungan berpikir kritis terhadap hasil belajar siswa di kelas eksperimen dan di kelas kontrol.

\section{METODE PENELITIAN}

Penelitian ini dilaksanakan di SMA Negeri 16 Medan dan waktu pelaksanaannya pada Tahun Pelajaran 2014/2015 Semester II. Populasi dalam penelitian ini adalah seluruh siswa kelas X SMA Negeri 16 Medan T.P 2014/2015 berjumlah 4 kelas.Pada penelitian ini sampel terdiri dari dua kelas yang dipilih dengan teknik cluster random sampling yaitu kelas X-Mia 3 sebagai kelas eksperimen yang menerapkan model pembelajaran Berdasarkan Masalah dan kelas $\mathrm{X}-\mathrm{Mia}_{2}$ sebagai kelas kontrol dengan menerapkan model pembelajaran konvensional. Jenis penelitian yang digunakan dalam penelitian ini adalah quasi eksperiment. Desain penelitian yang digunakan yaitu Two group pre test-pos test design seperti yang terlihat pada tabel 1 berikut ini. 
Tabel 1.Two group pre-test-post-test design

\begin{tabular}{lccc}
\hline \multicolumn{1}{c}{ Kelas } & Pretes & Perlakuan & Postes \\
\hline Eksperimen & $\mathrm{T}_{1}$ & $\mathrm{X}_{1}$ & $\mathrm{~T}_{2}$ \\
Kontrol & $\mathrm{T}_{1}$ & $\mathrm{X}_{2}$ & $\mathrm{~T}_{2}$ \\
\hline
\end{tabular}

Keterangan :

$\mathrm{T}_{1} \quad: \quad$ Tes pertama (pre-test)

$\mathrm{T}_{2} \quad$ : Tes akhir (pos-test)

$\mathrm{X}_{1}$ : Perlakuan pada kelas eksperimen dengan menggunakan model pembelajaran PBM

$\mathrm{X}_{2} \quad$ : Perlakuan pada kelas kontroldengan menggunakan pembelajaran konvensional

Instrumen yang digunakan dalam penelitian ini adalah tes hasil belajar dan kemampuan berpikir kritis sebanyak 8 soal uraiansetelah divalidkan yang akan diberikan pada pre-test dan post-test.

Pelaksanaan penelitian berlangsung masing-masing 4 kali pertemuan pada kelas eksperimen maupun kelas kontrol berdasarkan 4 buah Rencana Pelaksanan Pembelajaraan (RPP) yang telah dirancang pada saat sebelum penelitian dilakukan. Pada kelas eksperimen peneliti menerapkan model pembelajaran Problem Based Learning dengan menggunakan media powerpoint sedangkan pada kelas kontrol peneliti menerapkan pembelajaran langsung. Penerapan model pembelajaran Problem Based Learning ditujukan untuk melihat ada atau tidaknya perbedaan keterampilan pemecahan masalah dan berpikir kritis dengan siswa pada kelas kontrol.

Penerapan model pembelajaran problem based learning di kelas eksperimen dimulai dengan membentuk kelompok siswa menjadi 8 kelompok dengan masing-masing kelompok terdiri dari 5 sampai 6 orang siswa. Kemudian guru memberikan demonstrasi yang membuat siswa bingung dan tertarik terhadap materi. Hal ini bertujuan untuk memancing siswa bertanya seputar demonstrasi yang diberikan guru. Melalui pertanyaan yang mereka sampaikan, mereka kemudian diinstruksikan untuk melakukan praktikum untuk menguji hipotesis yang telah mereka buat.

Eksperimen yang dilakukan oleh siswa bertujuan untuk melatih keterampilan pemecahan masalah siswa. Siswa melakukan eksperimen dengan mengikuti lembar kerja siswa. Selama siswa melakukan praktikum, guru dibantu oleh dua orang teman sejawat melakukan observasi keterampilan pemecahan masalah siswa dengan menggunakan rubrik yang telah dipersiapkan. Hal ini bertujuan untuk melihat secara langsung keterampilan pemecahan masalah siswa di samping pemberian tes diakhir pembelajaran. Setelah eksperimen selesai, siswa diminta untuk memverifikasi hasil eksperimen mereka dan membuat kesimpulan pada setiap praktikum yang mereka lakukan

\section{HASIL DAN PEMBAHASAN}

\subsection{Hasil Penelitian}

Berdasarkan tes hasil belajar yang telah dilakukan di SMA Negeri 16 Medan diperoleh data pretes untuk kelas eksperimen dengan jumlah siswa 40 orang memperoleh nilai rata-rata sebesar 64,59 dan kelas kontrol 60,82. Data yang diperoleh ditunjukkan pada tabel 2. 
Tabel 2.Data Nilai Pretes Kelas Eksperimen dan Kelas Kontrol

\begin{tabular}{cccccc}
\hline \multicolumn{3}{c}{ Kelas } & Eksperimen & \multicolumn{3}{c}{ Kelas Kontrol } \\
\hline Nilai & $\mathbf{F}_{\mathbf{i}}$ & Rata-rata & Nilai & $\mathbf{F}_{\mathbf{i}}$ & Rata-rata \\
$\mathbf{3 4 - 4 2}$ & 9 & & $34-42$ & 10 & \\
$\mathbf{4 3 - 5 0}$ & 5 & & $43-50$ & 7 & \\
$\mathbf{5 1 - 5 8}$ & 1 & & $51-58$ & 0 & \\
$\mathbf{5 9 - 6 6}$ & 2 & 64,59 & $59-66$ & 3 & $\mathbf{6 0 , 8 2 5}$ \\
$\mathbf{6 7 - 7 4}$ & 6 & & $67-74$ & 6 & \\
$\mathbf{7 5 - 8 2}$ & 9 & & $75-82$ & 10 & \\
$\mathbf{8 3 - 9 0}$ & 8 & & $83-90$ & 4 & \\
\hline Jumlah & $\mathbf{4 0}$ & & Jumlah & $\mathbf{4 0}$ & \\
\hline
\end{tabular}

Data postes untuk kelas eksperimen dengan jumlah siswa 40 orang memperoleh nilai rata-rata postes sebesar 90,65 dan kelas Kontrol 79,40. Data yang diperoleh ditunjukkan pada tabel 3 .

Tabel 3.Data Nilai Postes Kelas Eksperimen dan Kelas Kontrol

\begin{tabular}{cccccc}
\hline \multicolumn{2}{c}{ Kelas } & Eksperimen & \multicolumn{4}{c}{ Kelas Kontrol } \\
\hline Nilai & $\mathbf{F}_{\mathbf{i}}$ & Rata-rata & Nilai & $\mathbf{F}_{\mathbf{i}}$ & Rata-rata \\
$\mathbf{7 7 - 8 1}$ & 3 & & $34-42$ & 1 & \\
$\mathbf{8 2 - 8 5}$ & 1 & & $43-50$ & 0 & \\
$\mathbf{8 6 - 8 9}$ & 1 & & $51-58$ & 0 & \\
$\mathbf{9 0 - 9 3}$ & 11 & 93,65 & $59-66$ & 1 & $\mathbf{7 9 , 4 0}$ \\
$\mathbf{9 4 - 9 7}$ & 12 & & $67-74$ & 9 & \\
$\mathbf{9 8 - 1 0 0}$ & 12 & & $75-82$ & 11 & \\
& & & $83-90$ & 18 & \\
\hline Jumlah & $\mathbf{4 0}$ & & Jumlah & $\mathbf{4 0}$ & \\
\hline
\end{tabular}

Hasil uji korelasi dengan menggunakan data pre-test diperoleh harga $t_{\text {hitung }}<t_{\text {tabel }}$ berarti $H_{a}$ diterima. Data yang diperoleh ditunjukkan pada tabel 4.

Tabel 4 Perhitungan Tes Berfikir Kritis

\begin{tabular}{lcccc}
\hline \multicolumn{1}{c}{ Data kelas } & $\mathbf{r}_{\text {hitung }}$ & $\mathbf{t}_{\text {hitung }}$ & $\mathbf{t}_{\text {tabel }}$ & Keterangan \\
\hline $\begin{array}{l}\text { Eksperimen } \\
\text { Kontrol }\end{array}$ & 0,06 & 0,37 & 2,024 & Tidak Terdapat Hubungan Yang Signifikan \\
\hline
\end{tabular}

Kedua kelas signifikan berbeda. Kelas eksperimen dengan keterampilan berpikir kritis rendah lebih baik dari kelas kontrol dengan keterampilan berpikir kritis tinggi. Kedua kelas signifikan tidak berbeda untuk kedua kelompok. Pada hal ini kedua variabel bebas tidak terjadi dominasi antara penggunaan model pembelajaran dan keterampilan berpikir kritis siswa.Kedua kelas signifikan tidak berbeda. Kelas eksperimen dengan keterampilan berpikir kritis rendah lebih baik dari kelas kontrol dengan keterampilan berpikir kritis rendah. Kedua kelas signifikan berbeda dengan interaksi kelas eksperimen dengan keterampilan berpikir kritis tinggi lebih baik dari kelas kontrol dengan keterampilan berpikir kritis rendah. 


\subsection{PEMBAHASAN}

Hasil analisis data penelitian menunjukkan bahwa data yang diperoleh terdistribusi dengan normal dan sampel berasal dari popilasi yang homogen. Hasil penelitian menunjukkan bahwa ada perbedaan akibat pengaruh model Pembelajaran Berdasarkan Masalah (PBM) terhadap hasil belajar pada materi pokok suhu, kalor dan perpindahan kalor di SMA Negeri 16 Medan bila dibandingkan dengan peembelajaran konvensional. Hal ini dapat dilihat melalui data hasil penelitian yang diperoleh dimana rata-rata pre-test kelas eksperimen sebesar64,59 dan kelas kontrol sebesar 60,825. Hasil tersebut dibawah KKM sehingga dikatakan tidak tuntas. Setelah diberikan perlakuan yang berbeda kelas eksperimen diberi pembelajaran dengan model PBM dan kelas kontrol pembelajaran konvensional diperoleh rata-rata kelas eksperimen 93,65 dan kelas kontrol sebesar 79,40. Hasil tersebut di atas nilai KKM dan dinyatakan tuntas.

Model pembelajaran berdasarkan masalah memiliki kelebihan-kelebihan yaitu salah satunya mampu untuk berfikir kritis. Peneliti ingin melihat hubungan berfikir kritis terhadap hasil belajar siswa sehingga peneliti memberikan tes kemampuan berfikir kritis yang dilakukan hanya satu yang terdiri dari 10 soal essay kepada kedua sampel. Analisi pengujian menggunakan analisis korelasi dengan kriteria pengujian jika $t_{\text {hitung }}>t_{\text {tabel }}$ maka terdapat hubungan yang signifikan antara berfikir kritis terhadap hasil belajar. Hasil penelitian menunjukkan bahwa tidak terdapat hubungan yangsignifikan antara berfikir krtitis terhadap hasil belajar dengan perolehan $t_{\text {hitung }}<t_{\text {tabel }}$.

Peningkatan hasil belajar siswa di kelas eksperimen ini dikarenakan pada saat proses pembelajarandengan menggunakan model PBMdiberikan LKS yang berisi berbagai masalah yang berkaitan dalam kehidupan sehari-hari sesuai materi pembelajaran. Masalah tersebut berfungsi sebagai batu loncatan untuk investigasi dan penyelidikan. Selain itu, siswa didorong untuk bekerja sama dalam memecahkan masalah tersebut dan menemukan sendiri informasi yang berkaitan dengan masalah. LKS yang berisi berbagai masalah tanpa ada prosedur percobaan akan membangkitkan rasa ingin tahu siswa, sehingga tertarik untuk melakukan penyelidikan, sehingga keterampilan siswa meningkat.

Hal yang berbeda ditemukan kelas kontrl dengan model pembelajaran konvensional, siswa belajar lebih banyak mendengarkan penjelasan di depan kelas dan melaksanakan tugas jika diberikan latihan soal-soal kepada siswa. Sistempengajaran konvensional yang dilakukan dalam proses belajar mengajar yaitu dengan menggunakan metode ceramah, tanya jawab, sehingga siswa pun merasa bosan, pasif, mudah cepat lupa dan siswa kurang kreatif. Hal ini diperkuat dengan rata-rata hasil belajar lebih rendah dibandingkan dengan model pembelajaran PBM.

Model PBM memiliki 5 sintaks yang dilakukan peneliti selama melakukan penelitian di SMA Negeri 16 Medan. Pada tahap pertama (orientasi siswa pada masalah), peneliti memotivasi siswa dengan memberikan tujuan pembelajaran yang akan dicapai oleh siswa dan pada tahap ini peneliti memberikan masalah kepada siswa dengan memberikan pertanyaan sederhana yang berbeda di dalam kehidupan sehari-hari siswa. Pada tahap kedua (mengorganisasi siswa untuk belajar), peneliti membentuk kelompok belajar yang heterogen dan membagikan LKS.Pada tahap ketiga (penyelidikan individual maupun kelompok), peneliti membimbing setiap siswa untuk mengumpulkan informasi melalui eksperimen untuk memecahkan masalah, dan melakukan diskusi kelompok sekali lagi. Pada tahap keempat (mengembangkan dan menyajikan hasil karya), peneliti membantu setiap kelompok menyelesaikan laporan hasil eksperimen. Pada tahap kelima (menganalisis dan mengevaluasi proses mengatasi masalah), peneliti membantu siswa dalam mengkaji ulang pemecahan masalah sesuai dengan tujuan pembelajaran dan materi pembelajaran. 
Menurut Arends (2008) model PBM tidak dirancang untuk membantu guru menyampaikan informasi dengan jumlah besar kepada siswa. Namun, PBM dirancang untuk membantu siswa mengembangkan keterampilan penyelidikan, keterampilan menyelesaikan masalah, dan keterampilan intelektualnya; mempelajari peran-peran orang dewasa dengan mengalaminya melalui berbagai situasi rill atau situasi yang disimulasikan; dan menjadi pelajar yang madiri dan otonom.

Beberapa penelitian yang relevan dengan penelitian ini seperti dalam Syahfitri (2014) juga diperoleh adanya ada perbedaan hasil belajar siswa menggunakan pembelajaran berdasarkan masalah dengan model pembelajaran konvensional dapat dilihat dari nilai rata-rata. Nilai ratarata di kelas dengan menggunakan model PBM sebesar 82,83 dan nilai rata-rata di kelas dengan menggunakan pembelajaran konvensional sebesar 76,83. Ahmad (2013) melakukan penelitian model PBMdi SMP N 5 Pematangsiantar menyatakan bahwa terdapat perbedaan hasil belajar siswa yang signifikan dengan menggunakan model pembelajaran berdasarkan masalah dengan pembelajaran konvensional. Sulaiman (2010) menyatakan bahwa Siswa memperoleh manfaat dari PBL, yaitu kemampuan komunikasi mereka ditingkatkan, pengetahuan mampu meraka bagikan bersama, itu mampu membantu untuk mengerti konsep dalam fisika modern. Selcuk (2010) menyimpulkan bahwa Model PBL lebih efektif daripada model tradisional dalam meningkatkan hasil belajar siswa.

Hal yang sama juga diperoleh oleh Darius (2010)hasil belajar siswa dengan menggunakan model pembelajaran berdasarkan masalah berbantu animasi macromedia flash pada materi listrik dinamis lebih besar dari kelas yang mendapatkan pembelajaran tradisional. Saputra (2011) menyimpulkan bahwa pada kelas yang menggunakan model PBL,setiap aspek keterampilan berpikir kreatif mengalami peningkatan elabordan berada dalam kategori sedang baik aspek elaborasi dan fleksibilitas.

Walaupun terjadi peningkatan hasil belajar dan keterampilan berpikiri kreatif, namun dalam melakukan penelitian peneliti mengalami kendala.Yang menjadi kendala peneliti dalam melakukan penelitian ini adalah 1) jumlah siswa yang banyak dan pada saat diskusi besar peluang siswa untuk membicarakan yang di luar materi pembelajaran sehingga peneliti kurang maksimal membimbing siswa melakukan penyelidikan melalui eksperimen. 2) siswa tidak terbiasa melakukan praktikum, apalagi LKS yang disediakan peneliti tidak memiliki langkah-langkah eksperimen sehingga masih menggunakan banyak waktu untuk bertanya dalam melakukan eksperimen 3) peneliti sudah berusaha mengatur waktu sesuai dengan yang direncanakan dalam RPP, namun dalam pelaksanaan pembelajaran di dalam kelas, peneliti masih menemukan kekurangan waktu karena siswa lebih banyak menghabiskan waktu saat melakukan eksperimen sehingga pada akhirnya peneliti tidak maksimal melakukan refleksi dan evaluasi pembelajaran yang seharusnya dijelaskan pada tahap keempat dan tahap kelima.

\section{KESIMPULAN DAN SARAN}

\subsection{Kesimpulan}

Berdasarkan hasil analisis yang dilakukan dalam penelitian ini diperoleh kesimpulan bahwa 1) Hasil belajar fisika siswa pada materi pokok Suhu, Kalor dan Perpindahan Kalor denganmenerapkan model pembelajaran berdasarkan masalah tergolong tuntas, 2) Hasil belajar fisika siswa dengan mengunakan konvensional tergolong tuntas, 3) Ada pengaruh hasil belajar setelah menggunakan model pembelajaran berdasrkan masalah terhadap hasil belajarsiswa pada materi pokok Suhu, Kalor dan Perpindahan Kalor di kelas X IPA semester II T.P 2014/2015, hal ini dapat dilihat dari ketuntasan yag didapat di atas KKM, 4) Tidak 
terdapat hubungan yang signifikan antara berfikir kritis terhadap hasil belajar siswa di kelas eksperimen dan kontrol dari hasil yang didapat diperoleh persamaan $t_{\text {hitung }}<t_{\text {tabel }}$.

\subsection{Saran}

Berdasarkan penelitian yang telah dilakukan maka beberapa hal yang disarankan untuk peneliti lebih lanjut. Jika jumlah siswa banyak, sebaiknya menggunakan media interaktif untuk melakukan penelitian, sehingga maksimal dalam melakukan penyelidikan melalui eksperimen sehingga kelas lebih kondusif. Mengatur penggunaan waktu dengan baik, sehingga semua sintaks dalam PBM dapat terlaksana dengan baik. Karena model PBM tidak memiliki prosedur eksperimen pada lembar kerja siswa sebaiknya lebih maksimal dalam membimbing melakukan penyelidikan mandiri dan kelompok.

\section{DAFTAR PUSTAKA}

Ahmad H. A., (2007), Implementation of Problem-Based Learning (PBL) in Foundation PhysicsSubject, Journal Science Department, Centre of Science Study.

Arends, R. I., (2008), learning to Teach (Belajar untuk Mengajar) buku dua, Pustaka Belajar, Yogyakarta

Ennis, R. H., (1996), Critical Thinking, Prentice-Hall Inc, USA.

Filsaime, D. K., (2008), Menguak Kemampuan Berpikir Kritis dan Kreatif. Prestasi Pustakarya, Jakarta.

Fisher, A., (2009),Berpikir Kritis, Erlangga, Jakarta.

Padang, D. J., (2013), Pengaruh Model Pembelajaran Berdasarkan Masalah Berbantu Animasi Macromedia Flash Terhadap Hasil Belajar Siswa Pada Materi Listrik Dinamis Di Kelas X SMA Negeri 1 Tanjung Morawa T.A. 2013/2014, Skripsi, FMIPA, Unimed, Medan.

Pohan, A. F., (2013), Pengaruh model pembelajaran berdasarkan masalah terhadap hasil belajar siswa pada materi pokok listrik dinamis kelas IX SMP N 5 Pematangsiantar T.P 2012/201, Skripsi, FMIPA, Unimed, Medan.

Saputra, O., Nurjanah., Mansyur, J., (2011), Pengaruh Problem Based Learning Menggunakan Alat Sederhana Terhadap Keterampilan Berpikir Kreatif Siswa SMA Negeri 7 Palu, Jurnal Pendidikan Fisika Talukado.

Selcuk, G., Caliskan, S., (2010), A small-scale study comparing the impacts of problem-based learning and traditional methods on student satisfaction in the introductory physics course. Procedia Social and Behavioral Sciences, Turkey.

Sulaiman, F., (2010), Students' Perceptions of Implementing Problem-Based Learning in a Physics Course, Procedia Social and Behavioral Sciences, New Zealand

Syahfitri., (2014), Pengaruh model pembelajaran berdasarkan masalah terhadap hasil belajar siswa pada materi pokok usaha dan energi di kelas VIII semester I SMP Satria Darma Perbaungan T.P 2013/2014, Skripsi, FMIPA, Unimed, Medan.

Yunita K., dan Mohan T. M., (2014), Pengaruh Pembelajaran Berbasis Masalah Dilengkapi Media Virtual Terhadap Aktivitas Dan Hasil Belajar Fisika SMA/Ma Volume 7 Nomor 2, Media Sains Jurnal Penelitian 